\title{
Low-P tolerance mechanisms and differential gene expression in contrasting wheat genotypes
}

\author{
Laize Fraga Espindula(1), Euclydes Minella ${ }^{(2)}$ and Carla Andréa Delatorre(1)
}

(1)Universidade Federal do Rio Grande do Sul, Departamento de Plantas de Lavoura, Programa de Pós-graduação em Fitotecnia, Caixa Postal 15100, CEP 90001-970 Porto Alegre, RS, Brazil. E-mail: laizesp@yahoo.com.br, cadtorre@ufrgs.br (2)Embrapa Trigo, Caixa Postal 451, CEP 99001-970 Passo Fundo, RS, Brazil. E-mail: eminella@cnpt.embrapa.br

\begin{abstract}
The objectives of this study were to determine low-P tolerance mechanisms in contrasting wheat genotypes and to evaluate the association of these mechanisms to differential gene expression. Wheat seedlings of cultivars Toropi (tolerant to low-P availability) and Anahuac (sensitive) were evaluated. Seedlings were hydroponically grown in the absence or presence of $\mathrm{P}\left(1.0 \mathrm{mmol} \mathrm{L}^{-1}\right)$ during three different time periods: 24,120 and 240 hours. Free phosphate $(\mathrm{Pi})$ and total $\mathrm{P}$ contents were measured in shoots and roots. The experiment's design was in randomized blocks with three replicates, each formed by ten plants. The relative expression of genes encoding the malate transporter TaALMT1 and the transcription factor PTF1 was evaluated. Phosphorus starvation beyond ten days increased the expression of TaALMT1 only in 'Toropi'. PTF1's expression was early induced in both genotypes under P starvation, but remained significant after ten days only in 'Toropi'. Shoot Pi concentration in 'Toropi' was independent from P availability; under starvation, 'Toropi' favored the maintenance of shoot Pi concentration. The low-P tolerance of Toropi cultivar at initial growth stages is mainly due to its ability to maintain constant the Pi shoot level.
\end{abstract}

Index terms: Triticum aestivum, phosphorus starvation, translocation.

\section{Mecanismos de tolerância à deficiência de fósforo e expressão diferenciada de genes em genótipos de trigo contrastantes}

\begin{abstract}
Resumo - Os objetivos deste estudo foram determinar os mecanismos da tolerância à deficiência de $\mathrm{P}$ em genótipos de trigo contrastantes e avaliar a associação desses mecanismos à expressão diferenciada de genes. Foram avaliadas plântulas das cultivares de trigo Toropi (tolerante à deficiência de $\mathrm{P}$ ) e Anahuac (sensível). As plântulas foram cultivadas em hidroponia, na ausência ou presença $\left(1,0 \mathrm{mmol} \mathrm{L}^{-1}\right)$ de $\mathrm{P}$, durante três períodos de tempo: 24, 120 e 240 horas. Os teores de fosfato livre ( $\mathrm{Pi}$ e e $\mathrm{P}$ total foram medidos na parte aérea e nas raízes. O delineamento experimental foi em blocos ao acaso com três repetições, cada uma formada por dez plantas. Foi avaliada a expressão relativa dos genes que codificam o transportador de malato TaALMT1 e o fator de transcrição $P T F 1$. Períodos de deficiência de $\mathrm{P}$ superiores a dez dias aumentaram a expressão de TaALMT1 somente em 'Toropi'. A expressão de PTF1 foi induzida em ambos os genótipos no início da deficiência, porém manteve-se significativa após dez dias somente em 'Toropi'. A concentração de Pi livre na parte aérea em 'Toropi' foi independente da disponibilidade de P; sob limitação, 'Toropi' favoreceu a manutenção da concentração de Pi na parte aérea. A tolerância à deficiência de $\mathrm{P}$ em 'Toropi' nos estádios iniciais de crescimento é devida principalmente à sua capacidade de manter constante a concentração de Pi na parte aérea.
\end{abstract}

Termos para indexação: Triticum aestivum, deficiência de fósforo, translocação.

\section{Introduction}

Phosphorus (P) affects all biological processes and is a pivotal component of the energy metabolism. Plants struggle to extract this essential element from the soil due to phosphate's low rate of diffusion and availability. Because of inorganic interactions and the formation of organic chemical complexes (Richardson, 1994), around $80 \%$ of the applied P may be fixed in the soil (Holford, 1997). It is estimated that 5.7 billion hectares of the soils worldwide have some degree of P deficiency (Batjes,
1997), and in Brazil, this rate is of over 50\% (Olmos \& Camargo, 1976).

Plants that have evolved in poor $\mathrm{P}$ environments developed several strategies to cope with inadequate $\mathrm{P}$ supply. Differences in P acquisition and use efficiency have been observed not only among plant species, but also among individuals of the same species (Gaume et al., 2001; Li et al., 2007).

Understanding the plant response to $\mathrm{P}$ deficiency and using genotypic differences for increasing $\mathrm{P}$ use efficiency within crop species may result in the 
development of low-P tolerant cultivars, which may reduce the demand for phosphate without affecting crop yield.

Low $\mathrm{P}$ availability associated to $\mathrm{Al}$ toxicity in soils from climate-adequate wheat-growing areas in the south of Brazil motivated the selection of low-P tolerant wheat genotypes. Several studies have observed differences among genotypes, either in soil or in hydroponic solution (Lyness, 1936; Silva et al., 2008), and show evidences for the existence of variability among cultivars in relation to $P$ uptake and use efficiency, which drives to the ability to tolerate P deficiency.

Root morphological and architectural modifications, organic acid secretion and specific Phosphate-transporter induction are known to affect the capacity of plants to obtain P from the soil. Tolerance may also be related to $\mathrm{P}$ use efficiency at low cellular free phosphate (Pi) levels, efficient allocation, and higher $\mathrm{Pi}$ mobilization from reserves (Abel et al., 2002; Kochian et al., 2004).

Physiologically, low-P tolerance involves the genotype ability to access, uptake, distribute and use the nutrient for biomass production. These capacities are established by morphological and physiological factors, and by the plant's nutritional demand.

Wheat is originated from the Middle East, a region of alkaline soils. However, in Brazil, wheat lines were selected for their ability to grow in acid soils. The Toropi cultivar, released in 1965 (Sousa, 1998), is well known for its Al and low-P tolerance (Rosa \& Camargo, 1990), which has been associated to the greater root volume produced by this cultivar (Wiethölter, 2004). Anahuac cultivar, on the other hand, is responsive to increasing $\mathrm{P}$ availability and is sensitive to low $\mathrm{P}$.

Organic acid secretion has been suggested as the main mechanism in $\mathrm{Al}$ as well as in low-P tolerance for several species (Kochian et al., 2004; Sasaki et al., 2004; Liu et al., 2009). TaALMT1 gene, which codifies a malate transporter, was the first gene identified in Al tolerance, but its role in low-P tolerance is not known (Sasaki et al., 2004). It will be interesting to evaluate its expression at low-P condition in tolerance-contrasting genotypes. OsPTF 1 was identified in rice as a major transcription factor involved in low-P tolerance (Yi et al., 2005). Based on the assumption that transcription factors are the best choice for tolerance transfer using transgenes, the knowledge whether cultivar tolerance is associated to the expression of genes such as PTF1 is of great relevance.

The objective of this study was to determine low-P tolerance mechanisms in wheat and to evaluate if tolerance is associated to differential gene expression in contrasting wheat genotypes.

\section{Materials and Methods}

Wheat (Triticum aestivum L.) cultivars Anahuac, sensitive to low-P and aluminum, and Toropi, used as source for tolerance in breeding programs (Ben \& Dechen, 1998; Freitas et al., 1999; Abichequer et al., 2003; Camargo et al., 2006; Silva et al., 2008), were the plant materials used in this study.

Seeds were disinfested, germinated in filter paper at $23 \pm 1^{\circ} \mathrm{C}$. Seedlings with similar root length were transferred to plastic screens adapted to the top of 3-L plastic pots. After endosperm removal, the seedlings were evenly distributed $2 \mathrm{~cm}$ apart. The experiment was conducted in a growth chamber maintained at $21 \pm 1^{\circ} \mathrm{C}$ temperature, with constant light and under aeration.

The nutrient solution used was that described by Camargo \& Oliveira (1981) adapted by Nava et al. (2006). The solution was changed every 48 hours, and had the following composition: $4 \mathrm{mmol} \mathrm{L}^{-1} \mathrm{Ca}\left(\mathrm{NO}_{3}\right)_{2} ; 2 \mathrm{mmol} \mathrm{L}^{-1}$ $\mathrm{MgSO}_{4} ; 4 \mathrm{mmol} \mathrm{L}-1 \mathrm{KNO}_{3} ; 0,435 \mathrm{mmol} \mathrm{L}^{-1}\left(\mathrm{NH}_{4}\right)_{2} \mathrm{SO}_{4}$; $2 \mu \mathrm{mol} \mathrm{L}-1 \mathrm{MnSO}_{4} ; 0,3 \mu \mathrm{mol} \mathrm{L}-1 \mathrm{CuSO}_{4} ; 0,8 \mu \mathrm{mol} \mathrm{L}^{-1}$ $\mathrm{ZnSO}_{4} ; 3 \mu \mathrm{mol} \mathrm{L}{ }^{-1} \mathrm{NaCl} ; 0,9 \mu \mathrm{mol} \mathrm{L}{ }^{-1}$ Fe-Geo Fe6; $0,10 \mu \mathrm{mol} \mathrm{L} \mathrm{Na}_{2} \mathrm{MoO}_{4}$ and $10 \mu \mathrm{mol} \mathrm{L} \mathrm{L}^{-1} \mathrm{H}_{3} \mathrm{BO}_{3}$. This solution didn't contain $\mathrm{P}(-\mathrm{Pi})$. In the treatment without $\mathrm{P}$ restriction, $1 \mathrm{mmol} \mathrm{L}-1 \mathrm{KH}_{2} \mathrm{PO}_{4}$ was added to the nutrient solution $(+\mathrm{Pi})$. The $\mathrm{pH}$ was maintained at 5.8. Plants were grown for 24, 120 and 240 hours.

After germination, seedlings were hydroponically grown in the absence or presence of $\mathrm{P}\left(1.0 \mathrm{mmol} \mathrm{L}^{-1}\right)$ during three different time periods: 24, 120 and 240 hours. After that, ten plants from each sample were collected, washed with distilled water, divided in shoots and roots, put in liquid nitrogen, grounded, dried at $60^{\circ} \mathrm{C}$ for 48 hours and weighted. Free $\mathrm{Pi}$ and total $\mathrm{P}$ quantification were determined according to Ames (1966), with small modifications. For the Pi extraction, TCA 10\% substituted $\mathrm{HCl}$. The content of $\mathrm{Pi}$ and total $\mathrm{P}$ in the endosperm was also measured.

For the quantitative analysis of the expression, RT-PCR (Real-Time Polymerase Chain Reaction) was used. Primers for TaALMT1 (5'AAGAGCGTCCTTAATTCG3' and 5'CCTTACATGATAGCTCCAGGG3') and for OsPTF1 (5'GAGCAAGAAAAGCGGCAACTAAAG3' and 5'TACGAAATACCCTCTGACGATGAA3'), described by Sasaki et al. (2004) and Yi (2005), 
respectively, were used. The roots were collected and frozen in liquid nitrogen. Total RNA was obtained using the Concert Plant RNA Reagent kit (Invitrogen, Carlsbad, USA). Samples with $3 \mu \mathrm{g}$ of total RNA were treated with DNAse I (Invitrogen, Carlsbad, USA), and used to produce the complementary DNA strand with the SuperScript III Reverse Transcriptase (Invitrogen, Carlsbad, USA). The ABI 7300 Real-Time PCR System (Applied Biosystems, Foster City, USA) was used for amplification. Each reaction contained the $1 \mathrm{X}$ buffer, $0,06 \mu \mathrm{mol} \mathrm{L}^{-1} \mathrm{dNTPs}$, $3 \mathrm{mmol} \mathrm{L}-1 \mathrm{MgCl}_{2}$, SYBER Green $10^{-5} \mathrm{X}$, ROX Reference Dye $510^{-4} \mathrm{X}, 0,125 \mathrm{U}$ Taq Platinum (Invitrogen, Carlsbad, USA), $0,2 \mu \mathrm{mol} \mathrm{L}^{-1}$ forward and reverse primers, and 0,3 ug cDNA. The amplification was set at $50^{\circ} \mathrm{C}$ for $2 \mathrm{~min}$, $95^{\circ} \mathrm{C}$ for $2 \mathrm{~min}$ followed by 40 cycles: $95^{\circ} \mathrm{C}$ for $15 \mathrm{~s} ; 60^{\circ} \mathrm{C}$ for $15 \mathrm{~s} ; 72^{\circ} \mathrm{C}$ for $30 \mathrm{~s} ; 60^{\circ} \mathrm{C}$ for $1 \mathrm{~min}$; a final step was added to analyze dissociation.

The real-time PCR data was analyzed by the relative quantification method using the ABI 7300 System SDS software (Applied Biosystems, Foster City, USA). The reference control was 28S rRNA (5' CTGATCTTCTGTGAAGGGT 3' and 5' TGATAGAACTCGTAATGGGC 3', GenBank accession no. AY049041). Ct (cycle threshold) values were collected from three replicates. Only samples with standard deviation below 0.5 were used for each gene. The gene's relative expression was calculated by $2^{-(\Delta \Delta \mathrm{Ct})}$, where $\Delta \Delta \mathrm{Ct}=\left(\mathrm{Ct}_{\text {target }}-\mathrm{Ct}_{28 \mathrm{~S}}\right)_{-\mathrm{Pi}}-\left(\mathrm{Ct}_{\text {caliper }}-\mathrm{Ct}_{28 \mathrm{~S}}\right)_{+\mathrm{Pi}}($ Dussault $\&$ Pouliot, 2006). The curves were adjusted by the free-domain software LinRegPCR (Ramakers et al., 2003) considering efficiencies between 1.8 and 2.0, and $\mathrm{R}>0.99$ for points higher than 4; smaller values were discarded. The detection threshold was manually adjusted.

The experiments were designed as randomized blocks with three replicates. Plots were formed by ten plants. Data were submitted to ANOVA and Tukey's comparison test, at $5 \%$ probability, using the SAS software (SAS Institute, 1999).

\section{Results and Discussion}

Analysis of endosperm P concentration confirmed the need of endosperm removal in order to evaluate responses to low $\mathrm{P}$ at initial growth stages. The amount of $\mathrm{Pi}$ in the wheat endosperm was around $0.1 \%$ of the total dry mass $\left[0.8 \mathrm{~g} \mathrm{~kg}^{-1}\right.$ dry weight (DW)], and can be considered low. However, total $\mathrm{P}$ reaches $0.7 \%$ (6.5 $\left.\mathrm{g} \mathrm{kg}^{-1} \mathrm{DW}\right)$. A large part of this $\mathrm{P}$ is in the form of phytate, the main P reserve in seeds (Guttieri et al.,
2004), which becomes available during the germination and initial plant growth. Therefore, endosperm removal is essential to evaluate the P deficiency effect at initial stages of development, otherwise the $\mathrm{P}$ present in the endosperm is transferred and used by the plant, and no difference is observed among plants growing in solution with or without $\mathrm{P}$, at least until ten days after germination. Similar values of $\mathrm{Pi}(0.8 \pm 0.03$ and $0.7 \pm 0.01 \mathrm{~g} \mathrm{~kg}^{-1} \mathrm{DW}$ for 'Toropi' and 'Anahuac' respectively) and total $\mathrm{P}\left(7 \pm 0.03\right.$ and $6 \pm 0.50 \mathrm{~g} \mathrm{~kg}^{-1} \mathrm{DW}$ for 'Toropi' and 'Anahuac' respectively) were found in the endosperm for both genotypes. The seeds were produced at $\mathrm{P}$-sufficient condition, thus no difference was expected.

Tolerance to $\mathrm{P}$ deficiency may be reached by increasing the $\mathrm{P}$ uptake capacity. However, at low-P conditions, $\mathrm{P}$ contents reflect not only the plants ability to extract $\mathrm{P}$ from soils, but also their capacity of $\mathrm{P}$ remobilization and redistribution during the crop cycle. Phosphorus uptake capacity depends on several plant characteristics; one of them is the root density. The increase in root system superficial area increases the plant's ability to access and uptake P. Wiethölter (2004) suggests that the 'Toropi' genotype has a higher capacity of P extraction due to an extensive root system. No significant differences were observed, neither in root dry matter (Table 1) nor in root length, between 'Toropi' and 'Anahuac' growing in low-P in hydroponics, at least at the initial growth stages. However, it was possible to visualize differences in the tolerance of low-P conditions between genotypes, especially in the color of the shoot. Similar observations were described by Silva et al. (2008). The observed differences between genotypes may be related to different crop cycles: 'Anahuac' is classified as an early cycle variety, and 'Toropi', as a late cycle variety (Cunha et al., 1997). Some traits usually related to low-P tolerance, such as morphological root alterations, mycorrhyzae association and enzyme secretion capacity, are not pertinent in hydroponics studies, since the $\mathrm{P}$ in the solution is in the inorganic form and promptly available.

When wheat genotypes were submitted to $\mathrm{P}$ starvation, Pi concentration reduced (Table 1). This decline increased with time, probably because plant growth. Interestingly, despite the fact that the ratio between $\mathrm{Pi}$ concentration at $\mathrm{P}$ sufficiency and $\mathrm{P}$ starvation remained similar in both genotypes for roots (1.1, 2.7 and 1.8 for 'Toropi', and 1.3, 2.1 and 1.8 
for 'Anahuac' at 24, 120 and 240 hours respectively); for shoots, it differed dramatically between genotypes (1.40, 1.18 and 1.32 for 'Toropi', and 1.29, 2.46 and 3.44 for 'Anahuac' at 24, 120 and 240 hours respectively). An opposite response is observed between genotypes when the shoot:root ratio is calculated (Table 1). 'Toropi' tends to translocate more $\mathrm{P}$ to the shoots under starvation than 'Anahuac'.

In a previous study, it has been observed that 'Anahuac' markedly increased its Pi content in the shoot as the Pi availability in the solution increased from zero to $1,000 \mu \mathrm{mol} \mathrm{L}{ }^{-1}$, whereas 'Toropi' presented a more stable Pi concentration in the shoots (Silva et al., 2008). These data suggest that 'Toropi' has a stronger control over its shoot Pi content, which is partially independent from Pi availability.

Starvation of $\mathrm{P}$ also reduced the total $\mathrm{P}$ concentration in the tissues of both genotypes (Table 1). In the shoots, the effect was statistically significant at 240 hours for 'Toropi', and early at 120 hours for 'Anahuac'. Besides the high total $\mathrm{P}$ concentration in the shoot at $\mathrm{P}$ sufficiency, 'Toropi' kept the Pi levels similar to those at starvation (Table 1,2), which suggests a stronger control over the $\mathrm{P}$ partition. At

Table 1. Dry matter mass and phosphorus concentrations in shoots and roots of wheat seedlings submitted to different periods of $\mathrm{P}$ starvation $(24,120 \text { and } 240 \text { hours })^{(1)}$.

\begin{tabular}{|c|c|c|c|c|c|c|}
\hline \multirow[t]{2}{*}{ Treatments } & \multicolumn{2}{|c|}{$24 \mathrm{~h}$} & \multicolumn{2}{|c|}{$120 \mathrm{~h}$} & \multicolumn{2}{|c|}{$240 \mathrm{~h}$} \\
\hline & Shoot & Root & Shoot & Root & Shoot & Root \\
\hline & \multicolumn{6}{|c|}{$\mathrm{Pi}\left(\mathrm{g} \mathrm{kg}^{-1}\right)$} \\
\hline 'Toropi' P+ & $7.10 \mathrm{a}$ & $6.04 \mathrm{bc}$ & $8.01 \mathrm{a}$ & $6.57 \mathrm{abc}$ & $4.87 \mathrm{ab}$ & $2.62 b c$ \\
\hline 'Toropi' P- & $5.01 \mathrm{bc}$ & $5.71 b c$ & $6.75 \mathrm{ab}$ & $2.41 d$ & $3.68 \mathrm{bc}$ & $1.44 \mathrm{c}$ \\
\hline 'Anahuac' P+ & $6.78 \mathrm{ab}$ & $5.96 \mathrm{bc}$ & $7.98 \mathrm{a}$ & $5.21 \mathrm{abc}$ & $7.4 \mathrm{a}$ & $3.10 \mathrm{bc}$ \\
\hline \multirow[t]{2}{*}{ 'Anahuac' P- } & $5.22 \mathrm{bc}$ & $4.45 \mathrm{c}$ & $3.4 \mathrm{bcd}$ & $2.54 \mathrm{~cd}$ & $2.15 b c$ & $1.68 \mathrm{bc}$ \\
\hline & \multicolumn{6}{|c|}{ Total P $\left(\mathrm{g} \mathrm{kg}^{-1}\right)$} \\
\hline 'Toropi' P+ & $13.85 \mathrm{c}$ & $23.68 \mathrm{a}$ & $18.30 \mathrm{a}$ & $9.41 \mathrm{bc}$ & $18.06 \mathrm{a}$ & $3.10 \mathrm{~d}$ \\
\hline 'Toropi' P- & $15.58 \mathrm{bc}$ & $13.64 \mathrm{c}$ & $12.13 \mathrm{ab}$ & $4.90 \mathrm{c}$ & $3.91 \mathrm{~d}$ & $3.44 \mathrm{~d}$ \\
\hline 'Anahuac' P+ & $18.00 \mathrm{bc}$ & $19.63 \mathrm{ab}$ & $19.31 \mathrm{a}$ & $12.34 \mathrm{ab}$ & $7.32 \mathrm{c}$ & $13.50 \mathrm{~b}$ \\
\hline \multirow[t]{2}{*}{ 'Anahuac' P- } & $14.70 b c$ & $14,23 \mathrm{c}$ & $4.92 \mathrm{c}$ & $3,59 \mathrm{c}$ & $2.71 \mathrm{~d}$ & $2.76 \mathrm{~d}$ \\
\hline & \multicolumn{6}{|c|}{ Dry matter $(\mathrm{mg})^{(2)}$} \\
\hline 'Toropi' P+ & - & - & - & - & $18 \pm 1.0$ & $13 \pm 2.0$ \\
\hline 'Toropi' P- & - & - & - & - & $23 \pm 2.0$ & $13 \pm 0.8$ \\
\hline 'Anahuac' P+ & - & - & - & - & $21 \pm 2.0$ & $13 \pm 1.0$ \\
\hline \multirow[t]{2}{*}{ 'Anahuac' P- } & - & - & - & - & $17 \pm 3.0$ & $11 \pm 0.2$ \\
\hline & \multicolumn{6}{|c|}{ Pi shoot:root ratio } \\
\hline 'Toropi' P+ & \multicolumn{2}{|r|}{1.17} & \multicolumn{2}{|r|}{1.21} & \multicolumn{2}{|c|}{1.86} \\
\hline 'Toropi' P- & \multicolumn{2}{|r|}{0.88} & \multicolumn{2}{|r|}{2.80} & \multicolumn{2}{|c|}{2.55} \\
\hline 'Anahuac' P+ & \multicolumn{2}{|r|}{1.13} & \multicolumn{2}{|r|}{1.53} & \multicolumn{2}{|c|}{2.39} \\
\hline 'Anahuac' P- & \multicolumn{2}{|r|}{1,17} & \multicolumn{2}{|c|}{1,27} & \multicolumn{2}{|c|}{1,28} \\
\hline & \multicolumn{6}{|c|}{ Total P shoot:root ratio } \\
\hline 'Toropi' P+ & & \multicolumn{2}{|c|}{1.94} & \multicolumn{2}{|c|}{5.82} \\
\hline 'Toropi' P- & \multicolumn{2}{|r|}{1.14} & \multicolumn{2}{|c|}{2.47} & \multicolumn{2}{|c|}{1.14} \\
\hline 'Anahuac' P+ & \multicolumn{2}{|r|}{0.92} & \multicolumn{2}{|c|}{1.56} & 0.5 & \\
\hline 'Anahuac' P- & & 1.03 & & 1.37 & 0.9 & \\
\hline
\end{tabular}

$\mathrm{P}$ sufficiency, a great part of the $\mathrm{P}$ is probably kept stocked in the vacuole in organic form, such as phytate; under starvation, the stocks are reduced and there is a reduction in structural P, like phospholipids, in order to keep the Pi homeostasis (Vance et al., 2003).

Secretion of organic acids has been established as one of the main mechanisms for aluminum (Al) tolerance, as well as for low-P tolerance (Kochian et al., 2004; Liu et al., 2009). TaALMT1 encodes an Al-activated malate transporter (Sasaki et al., 2004) and it is considered to be specifically and constitutively expressed in root apices of Al-tolerant wheat lines. However, there is no information about its role in low-P tolerance in the absence of Al. When 'Toropi' and 'Anahuac' were compared in relation to TaALMT1 expression, a very different behavior was observed (Table 2). At 24 hours of $\mathrm{P}$ starvation, both genotypes increased the relative expression of this gene when compared with P sufficiency, although the relative expression was three times greater for 'Anahuac'. Nevertheless, at 120 hours 'Toropi' showed a small increase in the gene expression relative to 24 hours, and 'Anahuac' slightly repressed it. Moreover, at 240 hours, 'Toropi' showed a relative expression 15 times greater than 'Anahuac'. This suggests that, besides being expressed constitutively, TaALMT1 may have its expression increased by long-term P starvation in tolerant genotypes. The importance of malate secretion for the low-P tolerance in 'Toropi' and for how $A L M T 1$ is activated in the absence of $\mathrm{Al}$ remains to be studied. As discussed earlier, in hydroponics, where $\mathrm{P}$ is added in its inorganic form and the $\mathrm{pH}$ is kept close to 6.0, organic acid secretion should have no role in tolerance. However, in the soil it may increase the plant's capacity of $\mathrm{P}$ uptake.

In general, broad responses to stresses, such as $\mathrm{P}$ starvation, are controlled by one or more transduction

Table 2. Relative expression of the TaALTM1 and PTF1 genes in the roots of wheat cultivars Toropi and Anahuac after 24, 120 and 240 hours of $\mathrm{P}$ starvation. The internal control was $\mathrm{P}$ sufficiency $\left(1 \mathrm{mmol} \mathrm{L} \mathrm{m}^{-1}\right)$ and the endogenous control was the gene $28 S$.

\begin{tabular}{lccc}
\hline Genotypes & \multicolumn{3}{c}{ Relative gene expression } \\
\cline { 2 - 4 } & 24 & 120 & 240 \\
\hline & & $T a A L T M 1$ & 32 \\
Toropi & 1.5 & 2 & 1.5 \\
Anahuac & 5.0 & 4 & 1.3 \\
\hline & & $P T F 1$ & 1.1 \\
Toropi & 2.0 & 1.7 & \\
Anahuac & - & 1.2 &
\end{tabular}


pathways, depending on the stress extent and magnitude. The main players are transcription factors, which can affect the expression of several genes. OSPTF1 was identified as a transcription factor with a basic helix-loop-helix domain for tolerance to Pi starvation in rice (Yi et al., 2005). It affected the expression of 158 genes in rice, several related to $\mathrm{P}$ starvation. Using the primers designed for $O S P T F 1$, it was possible to amplify a sequence in wheat. Its relative expression was always greater in $\mathrm{P}$ starvation when compared to P sufficiency (Table 2). The 'Toropi' putative PTF1 expression was higher, yet not more expressive than that of 'Anahuac' at the three evaluated time spans, but both genotypes reduced the magnitude of the expression along the time. At 240 hours, 'Toropi' showed an expression $40 \%$ lower than at 24 hours, while 'Anahuac' showed only 25\% of its initial response. In rice, this gene was identified using suppressive subtraction hybridization after ten days (240 hours) of P limitation. The cloning of this gene and the comparison of both genotypes, especially in its promoter region, might shed some light on the low- $\mathrm{P}$ tolerance mechanism.

Recently, another transcription factor, STOP1, which is required for the AtALMT1 expression, was identified as involved in low-pH and $\mathrm{Al}$ tolerance in Arabidopsis thaliana (Iuchi et al., 2007). The identification of similar factors in wheat might help understand the interactions between low-P and $\mathrm{Al}$ tolerance.

Together, these data suggest that 'Toropi' uses more than one mechanism to cope with $\mathrm{P}$ limitation. It has a very extensive and branched root system, which allows better soil exploration and access to Pi. At P-starvation conditions, it increases the expression of malate transporters that, once activated, allow the release of phosphorus from chelates, increasing the Pi availability. 'Toropi' is also able to control and sustain the Pi content in the shoots over a wide variation of Pi availability. This ability may be crucial to keep the metabolism stable under diverse $\mathrm{Pi}$ availability situations and lead to tolerance and crop yield stability.

The increase in the Pi shoot:root ratio (Table 1) for 'Toropi' under Pi starvation suggests higher translocation efficiency from roots to shoots. It may be related to the activity, affinity and expression of $\mathrm{Pi}$ transporters involved in long-distance transport. Hamburger et al. (2002) identified PHO1, in A. thaliana, which encodes a protein involved in the control of $\mathrm{P}$ transport to xylem. It is possible that kinetic differences in a similar protein in
'Toropi' causes better control of xylem loading, leading to greater stability. The identification of homologs in wheat would be of great assistance in dissecting this response, but this is a hard task: in A. thaliana there are 11 members of the PHOI family, and only two of them are involved in xylem loading (Stefanovic et al., 2007). Moreover, these two members are regulated by independent transduction pathways.

\section{Conclusions}

1. Toropi's cultivar low-P tolerance at initial growth stages is mainly due to its ability to sustain a constant shoot Pi level.

2. Periods of $\mathrm{P}$ starvation longer than ten days increase the expression of malate transporters activated by $\mathrm{Al}(A L M T 1)$ in 'Toropi', which may be important in releasing Pi from soil chelates.

3. One transcription factor similar to OSPTF1 is induced early in the P-starvation condition both in tolerant and sensitive cultivars, but its expression is kept significant at long periods only in 'Toropi'.

\section{Acknowledgements}

To Fundação de Apoio à Pesquisa do Estado do Rio Grande do Sul, for financial support; to Coordenação de Aperfeiçoamento de Pessoal de Nível Superior, for a scholarship.

\section{References}

ABEL, S.; TICCONI, C.A.; DELATORRE, C.A. Phosphate sensing in higher plants. Physiologia Plantarum, v.115, p.1-8, 2002.

ABICHEQUER, A.D.; BOHNEN, H.; ANGUINONI, I. Absorção, translocação e utilização de fósforo por variedades de trigo submetidas à toxidez de alumínio. Revista Brasileira de Ciência do Solo, v.27, p.373-378, 2003.

AMES, B.N. Assay of inorganic phosphate, total phosphate and phosphatases. Methods in Enzymology, v.8, p.115-118, 1966.

BATJES, N.H. A world dataset of derived soil properties by FAO-UNESCO soil unit for global modeling. Soil Use and Management, v.13, p.9-16, 1997.

BEN, J.R.; DECHEN, A.R. Resposta diferencial de genótipos de trigo em relação a fósforo no solo. Pesquisa Agropecuária Brasileira, v.33, p.589-594, 1998.

CAMARGO, C.E. de O.; FELICIO, J.C.; FERREIRA FILHO, A.W.P.; LOBATO, M.T.V. Tolerância de genótipos de trigo comum, trigo duro e triticale à toxicidade de alumínio em soluções nutritivas. Bragantia, v.65, p.43-53, 2006. 
CAMARGO, C.E. de O.; OLIVEIRA, O.F. Tolerância de cultivares de trigo a diferentes níveis de alumínio em solução nutritiva e no solo. Bragantia, v.40, p.21-31, 1981.

CUNHA, G.R. da; SCHEEREN, P.L.; RODRIGUES, O.; DEL DUCA, L. de J.A.; FIORINI, M.C.; SILVA, C.F.L. e. Bioclimatologia de trigos sul-brasileiros. Revista Brasileira de Agrometeorologia, v.5, p.195-198, 1997.

DUSSAULT, A.A.; POULIOT, M. Rapid and simple comparison of messenger RNA levels using real-time pcr. Biological Procedures Online, v.8, p.1-10, 2006.

FREITAS, J.G. de; CANTARELLA, H.; CAMARGO, C.E. de O.; FERREIRA FILHO, A.W.P.; FELICIO, J.C.; PETTINELLI JÚNIOR, A.; RAMOS, V.J. Efeito do calcário e do fósforo na produtividade de grãos e seus componentes nos cultivares de trigo. Bragantia, v.58, p.375-386, 1999.

GAUME, A.; MACHLER, F.; DE LEON, C.; NARRO, L.; FROSSARD, E. Low P tolerance by maize genotypes: significance of root growth, and organic acids and acid phosphatase root exudation. Plant and Soil, v.228, p.253-264, 2001.

GUTTIERI, M.; BOWEN, D.; DORSCH, J.A.; RABOY, V.; SOUZA, E. Identification and characterization of a low phytic acid wheat. Crop Science, v.44, p.418-424, 2004.

HAMBURGER, D.; REZZONICO, E.; PETÉTOT, J.M.C.; SOMERVILLE, C.; POIRIER, Y. Identification and characterization of the Arabidopsis $\mathrm{PHO1}$ gene involved in phosphate loading to the xylem. Plant Cell, v.14, p.889-902, 2002.

HOLFORD, I.C.R. Soil phosphorus: its measurement, and its uptake by plants. Australian Journal of Soil Research, v.35, p.227-239, 1997.

IUCHI, S.; KOYAMA, H.; IUCHI, A.; KOBAYASHI, Y.; KITABAYASHI, S.; KOBAYASHI, Y.; IKKA, T.; HIRAYAMA, T.; SHINOSAKI, K.; KOBAYASHI, M. Zinc finger protein STOP1 is critical for proton tolerance in Arabidopsis and coregulates a key gene in aluminum tolerance. Proceedings of the National Academy of Sciences of the United States of America, v.104, p.9900-9905, 2007.

KOCHIAN, L.V.; HOEKENGA, O.A.; PIÑEROS, M.A. How do crop plants tolerate acid soils? Mechanisms of aluminum tolerance and phosphorous efficiency. Annual Review of Plant Biology, v.55, p.459-493, 2004.

LI, K.; XU, Z.P.; ZHANG, K.W.; YANG, A.F.; ZHANG, J.R. Efficient production and characterization for maize inbred lines with low-phosphorus tolerance. Plant Science, v.172, p.255-264, 2007.

LIU, J.P.; MAGALHÃES, J.V.; SHAFF, J.; KOCHIAN, L.V. Aluminum-activated citrate and malate transporters from the MATE and ALMT families function independently to confer Arabidopsis aluminum tolerance. The Plant Journal, v.3, p.389-399, 2009.

LYNESS, A.S. Varietal differences in the phosphorus feeding capacity of plants. Plant Physiology, v.1, p.665-688, 1936.
NAVA, I.C.; DELATORRE, C.A.; DUARTE, I.T. de L.; PACHECO, M.T.; FEDERIZZI, L.C. Inheritance of aluminum tolerance and its effects on grain yield and grain quality in oats (Avena sativa L.). Euphytica, v.148, p.353-358, 2006.

OLMOS, I.L.J.; CAMARGO, M.N. Aluminum toxicity in Brazilian soils: characterization and distribution. Ciência e Cultura, v.28, p.171-180, 1976.

RAMAKERS, C.; RUIJTER, J.M.; DEPREZ, R.H.L.; MOORMAN, A.F.M. Assumption-free analysis of quantitative real-time polymerase chain reaction (PCR) data. Neuroscience Letters, v.339, p.62-66, 2003.

RICHARDSON, A.E. Soil microorganisms and phosphorus availability. In: PANKHURST, C.E.; DOUBE, B.M.; GUPTA, V.V.S.R.; GRACE, P.R. (Ed.). Soil biota: management in sustainable farming systems. Melbourne: Australian Commonwealth Scientific and Research Organization, 1994. p.50-62.

ROSA, O.S.; CAMARGO, C.E.O. Wheat breeding for better efficiency in phosphorus use. In: INTERNATIONAL CONFERENCE ON WHEAT FOR THE NONTRADITIONAL WARMAREAS, 1990, Foz do Iguacu. Wheat for the nontraditional warm areas: proceedings. Mexico: CIMMYT, 1990. p.333-351.

SAS INSTITUTE. SAS software. Cary: SAS Institute, 1999.

SASAKI, T.; YAMAMOTO, Y.; EZAKI, B.; KATSUHARA, M.; AHN, S.J.; RYAN, P.R.; DELHAIZE, E.; MATSUMOTO, H. A wheat gene encoding an aluminum-activated malate transporter. The Plant Journal, v.37, p.645-653, 2004.

SILVA, A.A.D.; ARNS, I.; LIMA, C.V.S.; SCHNEIDER, A.D.B.; DELATORRE, C.A. Diferenciação de genótipos de trigo quanto à tolerância à deficiência de fósforo, em solução hidropônica. Revista Brasileira de Ciência do Solo, v.32, p.1949-1958, 2008.

SOUSA, C.N.A. de. Classification of Brazilian wheat cultivars for aluminium toxicity in acid soils. Plant Breeding, v.117, p.217221, 1998.

STEFANOVIC,A.;RIBOT,C.; ROUACHED,H.;WANG,Y.; CHONG, J.; BELBAHRI, L.; DELESSERT, S.; POIRIER, Y. Members of the PHO1 gene family show limited functional redundancy in phosphate transfer to the shoot, and are regulated by phosphate deficiency via distinct pathways. Plant Journal, v.50, p.982-994, 2007.

VANCE, C.P.; UHDE-STONE, C.; ALLAN, D.L. Phosphorus acquisition and use: critical adaptations by plants for securing a nonrenewable resource. New Phytologist, v.157, p.423-447, 2003.

WIETHÖLTER, S. Fósforo no solo e a cultura do trigo. In: SIMPÓSIO SOBRE FÓSFORO NA AGRICULTURA BRASILEIRA, 2003, São Pedro. Fósforo na agricultura brasileira: anais. Piracicaba: POTAFOS, 2004. p.457-494.

YI, K.; WU, Z.C.; ZHOU, J.; DU, L.; GUO, L.; WU, Y.; WU, P. OsPTF1, a novel transcription factor involved in tolerance to phosphate starvation in rice. Plant Physiology, v.138, p.2087-2096, 2005.

$\overline{\text { Received on February 6, } 2009 \text { and accepted on August 14, } 2009}$ 